\title{
Auplopus rectus (Haupt, 1927) (Hymenoptera: Pompilidae) - a new spider wasp species to the fauna of Poland
}

\author{
Petr BOGUSCH \\ Department of Biology, Faculty of Science, University of Hradec Králové, Rokitanského 62, \\ CZ-500 03 Hradec Králové, Czech Republic; e-mail: bogusch.petr@gmail.com
}

\begin{abstract}
Auplopus rectus (Haupt, 1927) is newly recorded from Poland. It was found on sandy site near Smołdzino, on the border of Słowiński National Park - the most northerly known locality of this species. The distribution of $A$. rectus in Central Europe and potential spreading are discussed.
\end{abstract}

Key words: spider wasp, new record, distribution, Słowiński National Park

\section{INTRODUCTION}

Spider wasps (Pompilidae) are not very numerous family of aculeate Hymenoptera with 89 species known from Poland (Wiśniowski 2009). The members of this family are gracile insects with long legs. Females have sting with strong venom. They hunt various groups of spiders, some species are specialized, e.g. Eoferreola rhombica (Christ, 1791) on Eresus Walckener, 1805; Aporus unicolor Spinola, 1808 on Atypus Latreille, 1804 or Homonotus sanguinolentus (Fabricius, 1793) on Cheiracanthium C. L. Koch, 1839. Many species are ecologically specialized and hunt spiders on leaves of shrubs or on bare sands. Some genera are cleptoparasitic, using different strategies to get prey and lay the eggs on it (O'Neill 2001, Wiśniowski 2009, Macek et al. 2010). In Europe, are known 284 species and most of them occur in warmer regions, so the distribution of most species is restricted to southern Europe (Wiśniowski 2009).

In central Europe are known three species of the genus Auplopus Spinola, 1841. They are medium in size, with short petiole on first abdominal segment and elongated clypeal margin in females. The males have white or pale yellow marks on the face. The females build their brood cells of mud on stones, walls or in different kinds of cavities. They are unspecialized and hunt for various spiders of many families (Wiśniowski 2009, Macek et al. 2010).

Auplopus carbonarius carbonarius (Scopoli, 1763) is a common species in many kinds of biotopes and it is abundant in most regions of Central Europe. Auplopus albifrons (Dalman, 1823) with first abdominal terga red prefers warmer regions where it is in the Czech Republic and Slovakia locally common (Macek et al. 2010). Both species occur in Poland, although A. albifrons has been recorded only from one locality in the Lublin Upland and it is classified as critically endangered (Wiśniowski 2009). Auplopus rectus (Haupt, 1927) is known from adjacent countries (the Czech Republic and Slovakia), but it is rare and occurs only on the sandy biotopes. Recently, it was found at the post-industrial sites, especially in sandpits or military exercising areas (Wolf 1971, P. Bogusch, unpubl. data). 


\section{METHODS}

The specimen was collected during the excursion of CEEPUS Summer School on sandy site near the village Smołdzino in north Poland. It was identified by the author and revised by Jakub Straka (Charles University, Praha, the Czech Republic) using the keys of Wolf (1972) and Oehlke \& Wolf (1987) and also material from Czech localities. Nomenclature is used from Wolf (1971) and Wiśniowski (2009).

\section{RESULTS}

\section{Auplopus rectus (Haupt, 1927)}

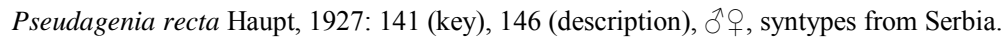

Material examined: Poland, Smołdzino env., sandy site, 54.664276 N, 17.206832 E, 15 Jul 2014, 1 \% , leg. P. Bogusch, det. \& coll. J. Straka revid.

Distribution: South and southeastern France, Switzerland, Austria, the Czech Republic, Slovakia, South East Europe, Spain, Portugal, Italy, Cyprus, Turkey, Iran (Wolf 1971). Wahis (2004) reported this species also from Albania, Bosnia, Corsica, Greece, Malta, Romania, Sardinia, and Sicily, eastern in central Russia, Near East and North Africa. It also occurs in southern Europe, reaching central Europe in Switzerland, the Czech Republic and Slovakia. It has not been recorded in Germany and Ukraine.

Remarks: One female was collected on the bare sand between the river and the stadium in Smołdzino in northern Poland. The female was running on the sand surface, probably trying to find a prey. Anoplius infuscatus (Vander Linden, 1827) and Arachnospila abnormis (Dahlbom, 1842) were found at the same locality, the former was quite numerous.

The nearest known localities of $A$. rectus are ca. $700 \mathrm{~km}$ far: in south Moravia (sandpits near Bratčice or military area Bzenec) and in south Slovakia (sandpit at Nemčiňany) (Fig. 1).

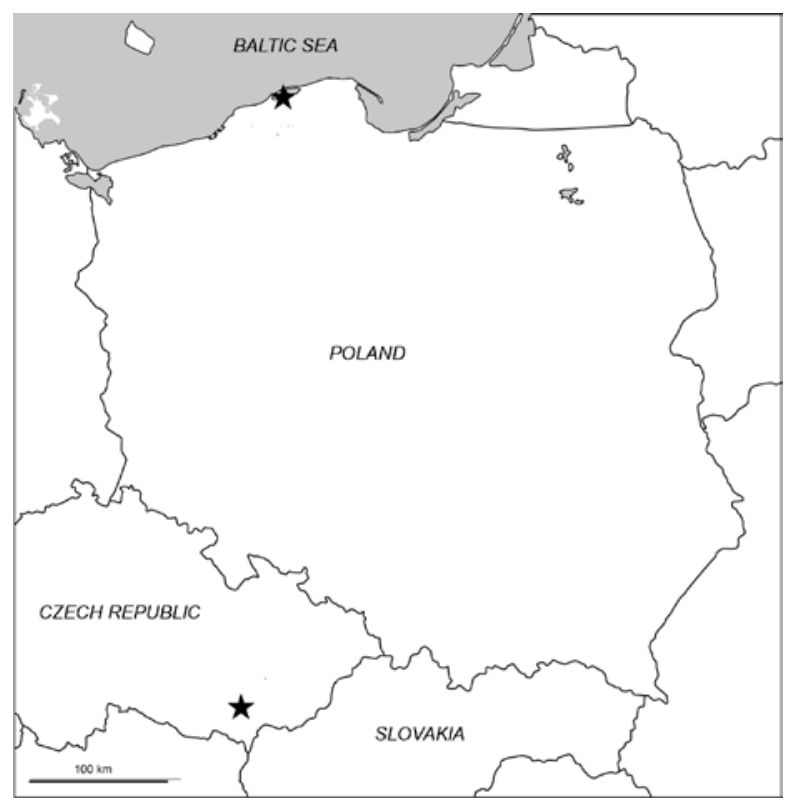

Fig. 1. Map of Poland and surrounding countries with marked new locality of Auplopus rectus in Pomerania in Poland and with the nearest locality in South Moravia in the Czech Republic. 
The habitat where the species was found in Poland is similar to those in Moravia and Slovakia. The dune is located in the unpolluted region with sandy soil, so this species is probably related to such habitat types. A. rectus was historically known from two sites in Bohemia (Praha and Únětice in central Bohemia) and from south Moravia and Slovakia (Wolf 1971). After that it disappeared from most of the localities and it was restricted only to the warmest sites. According to the red list of species, it is critically endangered in the Czech Republic (Straka 2005). In recent years, A. rectus was recorded many times in various parts of southern Moravia and it was quite numerous in some localities. Thus, it seems that this species spread to the north (P. Bogusch \& J. Straka, pers. obs.).

The current discovery supplements the Polish faunistic lists of the next spider wasp and it moves the northernmost range of the species.

\section{ACKNOWLEDGEMENTS}

I would like to thank to Leszek Rychlik (Adam Mickiewicz University Poznań, Poland) for the possibility to join the summer school and to Jakub Straka (Charles University, Praha, Czech Republic) for revision of the specimen.

\section{REFERENCES}

HAupt H. 1927. Monographie der Psammocharidae (Pompilidae) von Mittel-, Nord- und Ost-Europa. Beiheft der Deutsche Entomologische Zeitschrift 1926-1927: 1-367.

MACEK J., Straka J., Bogusch P., BeZdĚČKa P., Dvoř́́K L. \& TYRnER P. 2010. Blanokřídlí České republiky. I Žahadloví. Academia, Praha, 524 pp.

OeHLKe J. \& Wolf H. 1987. Beiträge zur Insekten-Fauna der DDR: Hymenoptera - Pompilidae. Beiträge zur Entomologie 37: 279-390.

O’NeILl K. 2001. Solitary Wasps: Behavior and Natural History. Cornell University Press, Ithaca and New York, xiv $+406 \mathrm{pp}$.

STRAKA J. 2005. Vespoidea - vosy. In: FARKAČ J., KRÁL D. \& ŠKORPíK M. (eds), Červený seznam ohrožených druhů České republiky. Bezobratlí. List of threatened species in the Czech Republic. Invertebrates, pp. 387-391. Agentura ochrany prírody a krajiny ČR, Praha, 760 pp.

WAHIS R. 2004. Pompilidae. Fauna Europaea version 2.6.2. Available at http://www.faunaeur.org/full_results.php?id=198849 (25 Oct 2014).

WiŚNIOWSKI B. 2009. Spider-Hunting Wasps (Hymenoptera: Pompilidae) of Poland. Diversity, Identification, Distribution. Ojców National Park, Ojców, 432 pp.

Wolf H. 1971. Prodromus der Hymenopteren der Tschechoslowakei. Pars 10: Pompiloidea. Acta Faunistica Entomologica Musei Nationalis Pragae 14: 3-76.

Wolf H. 1972. Hymenoptera Pompilidae. Insecta Helvetica Fauna 5, SEG edition, Zürich, 176 pp.

\section{STRESZCZENIE}

\section{[Auplopus rectus (Haupt, 1927) (Hymenoptera: Pompilidae) - nowy dla Polski gatunek nastecznika]}

Jedna samica nastecznika Auplopus rectus (Haupt, 1927) została zebrana w lipcu 2014 r. na piaszczystym terenie, w pobliżu Smołdzina w północnej Polsce (przy granicy Słowińskiego Parku Narodowego). Stanowisko jest osobliwe, ponieważ gatunek ten występował dotychczas w południowej Europie, z północną granicą zasięgu w Czechach (piaskownia w pobliżu Bratčice). Opisywane stanowisko podobne jest do czeskich, gdzie dotychczas obserwowano nastecznika. Na badanym stanowisku znaleziono także inny rzadki gatunek Arachnospila abnormis. W Czechach A. rectus wykazuje ekspansję. Prezentowane stanowisko jest prawdopodobnie najdalej wysuniętym na północ. 